\title{
The Zoning System for Strategy Development of SMEs Go Online: A Literature Review
}

\author{
Sumitro Sarkum ${ }^{1}$, Gomal Juni Yanris Silaen ${ }^{2}$, Iwan Purnama ${ }^{3}$, Muhammad Halmi Dar ${ }^{4}$, Ronal \\ Watrianthos ${ }^{5}$, Ibnu Rasyid Munthe ${ }^{6}$, Sudi Suryadi ${ }^{7}$, Marnis Nasution ${ }^{8}$, Decy Irmayani ${ }^{9}$, Sentosa \\ Pohan $^{10}$ \\ sumitro.ulb@gmail.com ${ }^{1}$, gomalsilaenpanggomal@gmail.com², iwanpurnama2014@gmail.com ${ }^{3}$, \\ mhd.halmidar@gmail.com ${ }^{4}$, mail.to.ronal@gmail.com ${ }^{5}$, ibnurasyidmunthe@ gmail.com 6 , \\ sudisuryadi28@gmail.com7 , marnisnst@gmail.com ${ }^{8}$, deacyirmayani@gmail.com ${ }^{9}$, \\ sentosaphn@gmail.com ${ }^{10}$
}

Akademi Manajemen Informatika Labuhan Batu ${ }^{1,2,3,4,5,6,7,8,9,10}$

\begin{abstract}
This study aims to figure out what the relationship of empowerment of SMEs through methods of zoning as marketing strategy of SMEs in two different markets (offline and online). The zoning strategy with information and communication system integrated brings together socialization and promotion in a market. This system can help the government in taking and formulating policies to unite SMEs in a new market by not leaving the old market. The method in this study uses qualitative descriptive. There are three propositions produced in this initial research, the first; Offline and online marketing is very relevant for SMEs in Indonesia. Second; marketing information system is access for SMEs to find out the demand or market needs both domestically and internationally. And third; The zoning system can be used as an online development strategy for SMEs to synchronize two different markets, namely offline and online. Further research is needed to validate the propositions found, to generate hypotheses and empirical evidence, we recommend using mix methods for future research.
\end{abstract}

Keyword: Promotion System, Market Information System, Zoning System, SMEs

\section{Introduction}

The development of SMEs Go Online continues to be the government's attention to date. The report of Yasmin (2018) currently the condition of SMEs in Indonesia dominates the business units up to $99,9 \%$ of the total 57,89 million. This figure also contributes to employment, gross domestic product (GDP) to exports. On the other hand 8,2 million of SMEs creative which grows and has the potential to expand its business. According to Head of Bank Indonesia SMEs Development Department, Yunita, in the report Fauzia (2018) states of a number 8,2 million of SMEs creative in Indonesia combined in one platform online, then it can defeat the giant e-commerce china, Alibaba. But until now the government is still working on the concept of SMEs Go Online to combine existing potential. Whereas SMEs creative have the potential to continue to experience export increases until they touch 19,9 million US with 4.6 percent growth in the year. While in global competition, especially in the Asia Pacific region, the contribution of Indonesian SMEs still reached 16 percent. This figure is still inferior to South Korea, Thailand, India and China (Primus, 2018). Whereas by switching to online, SMEs can avoid agents who play prices and strangle brokers (Momongan, 2018).

One of the obstacles SMES Go online is that SMEs players do not have access to find information about the demands or needs of both domestic and foreign markets. Based on the report Nurmayanti (2018) in his interview with the Speaker of the House Bambang Soesatyo who referred to the results of the research Mckinsey Institute, said 
that by the end of 2017 there were 59.9 million business units of SMEs in Indonesia. However, of that number only 3.97 million units of SMES are currently utilizing the digital realm. While Nurrohmah \& Alfanur (2016) stated that one of the obstacles of SMEs was marketing. The method that can be used is to use e-commerce. And using digital, SMEs can keep on going without having to shop (Sarkum, Pramuka, \& Suroso, 2017b).

\section{Literature Review}

\subsection{Promotion of SMEs}

Socializing SME activities related to governance of costs and growth cycles that have passed the pioneering stage of the business and have had an increase in the market (Wu \& Lu, 2012). That SMEs have gone through these phases will naturally face greater problems and challenges in achieving sustainability (Irjayanti and Azis, 2012). Therefore, the role of government and pioneering partners is needed to reduce the operational burden of SMEs in order to be competitive in a changing market (Sulistyowati, Pardian, Syamsyiah, \& Deliana, 2018). According Jaswadi, Iqbal and Sumiadji (2015) in managing SME management in Indonesia, a collaboration between the supervisory board and management is needed to produce innovative ideas for SMEs. Joint arrangement will also affect earnings management (Muda, Maulana, Siregar, \& Indra, 2018). The SMEs programs that have been planned by the government also need to be socialized and informed to SMEs so that the implementation of the program runs according to planning, such as seminars, training, exhibitions, capital assistance and other competitions that lack socialization to SMEs (Dhewanto, Lantu, Herliana, \& Azzahra, 2018). For the socialization, a budget and experts are needed (Mizanti, Simatupang, \& Larso, 2018).

Thus, to build strong SMEs, socialization is needed to all stakeholder and society (Rosmery, 2018). Furthermore, SMEs also need promotion, according to Rapini, Farida and Santoso (2018) development efforts still need help for promotion needs and the formation of marketing networks. Whereas to penetrate certain markets, for example International markets, insights from predecessors have been successful (Dhewanto et al., 2018). Besides this, SMEs need to be aware of the ever-changing market. A dynamic strategy is needed to overcome it. This effort is useful for the sustainability and readiness of SMEs in competitiveness in the market. At present the market is divided into two, namely offline and online. Mechanisms in both markets are different, but mutually supportive to achieve the success and sustainability of the SMEs business, a strong attachment is needed from customers, employees and the supply chain to carry out operational marketing functions in two different markets (Sarkum, Pramuka, \& Suroso, 2017a). The problem is the lack of SMEs that have a budget for marketing, still relying on conventional media and not realizing the importance a branding (Widyastuti, 2018). Even though there are still many ways to anticipate this, one of them is by using social media as a marketing medium. According to Kumar and Pradhan (2018) using social media, businesses can find direct and easy communication mechanisms with customers.

Ardyan and Sugiyarti (2018) suggest that choosing the right media can make interaction easier between SMEs and customers. Then by increasing shared 
information sharing activities will influence the improvement of product competitiveness and SMEs marketing performance. A final conclusion from Chan (2018) stated that the average corporate promotion strategy had been used in social media as the main strategy, but conventional media was still used. Thus the proposition can be drawn that offline and online marketing is very relevant for SMEs in Indonesia.

\subsection{Market Information System of SMEs}

The present, SME information systems need to be adapted to the ability of users (Astuti, Setyowati, \& Utama, 2018). The results of empirical research Lisnawati, Wibowo and Andi (2018) For 170 consumers on online trading sites in Indonesia, the development of online information systems requires quality security and information because it can affect purchases. This needs to be understood by SMEs as sellers because it is related to customer purchasing decisions. And to build a business environment using internet instruments such as e-commerce, e-business, e-media, and egovernment. Analysis Pamungkas et al. (2018) shows that many potential regulations and policies are needed to develop the environment as a central means of the market to encourage digital economy and learning within organizations.

The case studies conducted by Andriani et al. (2018) in the fashion industry companies that have grown on a national scale, the use of marketing media that collaborates on offline and online marketing development is more mature than that focused on offline. However, Amilia, Fatimatuzzahro and Choiron (2018) argued that the perspective and behavior of SMEs in running a business, building a marketing network and continuing existing cooperation are obstacles to business development. On the other hand, findings Rahman and Mawardi (2017) indicated that the inhibiting factor of SMEs was building a brand where the marketplace service was less than optimal, there was an official store, the difficulty of choosing products and suppliers, excessive consumer expectations, and man power. The same is found by Habyba, Djatna and Anggraeni (2018) in this case study stated the need for e-commerce website design. While Mercer (2016) Suggesting to enter the digital world of SMEs needs to learn how to start from choosing the right Web platform, the basics of internet marketing, email marketing, how to blog (specifically for business purposes) and marketing strategies as basic technical knowledge.

Based on the report Ika (2018) explained that the digital market contribution to Indonesia's Gross Domestic Product (GDP) has continued to increase since 2016, based on data from the Central Statistics Agency. This increase is because Indonesia is a potential market for the digital economy. In 2018, the digital market contribution is estimated at 10 percent, according to research by the Center for Indonesian Policy Studies (CIPS). SMEs empowerment it self is based Undang-Undang Republik Indonesia Nomor 7 Tahun 2014 Tentang Perdagangan (2014) chapter X clause 73 paragraph (2) states that the empowerment of micro, small and medium enterprises conducted by the Government and / or Regional Government can be in the form of, one of them is promotion and marketing assistance. Therefore the provision of information and market networks, easy access to funding and assistance and capacity building of information technology are some of the strategies to improve the competitiveness of Indonesian SMEs. Based on this, a proposition can be drawn that the marketing 
information system is an access for SMEs to find out the demand or market needs both domestically and internationally.

\subsection{The Zoning System of SMEs}

The Indonesian Wikipedia explains 'Pemintakatan' (2018) (English languange: zoning) is a land use planning method used by local governments in most developed countries (Lefcoe, 2005). Cahaya, Nugroho and P (2016) explained that the pemintakatan system was used as a reference in structuring the room by taking into account several important considerations in its placement.. The Study Kupita and Bintoro (2012) in the implementation of traditional and modern market integration policies, it is found that there is a lack of synchronization between the two markets so that it is not beneficial and detrimental to traditional warriors. Likewise with the results of the study Dakhoir (2018) said it could threaten the resilience of traditional markets and small businesses of the same kind and could trigger social insecurity (disharmony).

While the monitoring of mina and agro in a number of research evaluations stated that minapolitan pemintakatan still had problems with lack of market absorption (Rauf, 2016; Sormin, Risambessy and Ferdinandus, 2016). Therefore, a space is needed for market integration for every SME from various products, especially regional superior products in order to absorb products and provide services to SMEs in improving and supporting business sustainability. Spatial planning activities are regulated according to Act No. 24 of 1992 concerning spatial planning, covering the entire process of spatial planning, spatial utilization, and control of spatial utilization. The main considerations in spatial planning include the criteria for cultivation and non-cultivation areas in land use, the socio-economic conditions of the region and 'interest' (interest in the development sector, regional aspirations, links between regions and so on) ("Konsep Minapolitan," 2009). Based on this, a proposition can be drawn that the zoning system can be used as an online development strategy for SMEs to synchronize two different markets, namely offline and online.

\section{Methodology}

The method in this study uses qualitative descriptive. According to Kurniawan (2018) the aim of qualitative descriptive research is to describe what currently applies. In it there are efforts to describe, record, analyze and interpret conditions that currently occur or exist. In other words, this qualitative descriptive study aims to obtain information about the existing conditions. The collection of information and data is taken from documents related to research as a theoretical basis.

\section{Resulth \& Conclusion}

There are three propositions produced in this initial research, first; Offline and online marketing is very relevant for SMEs in Indonesia. Second; marketing information system is access for SMEs to find out the demand or market needs both domestically and internationally. And third; The zoning system can be used as an online development strategy for SMEs to synchronize two different markets, namely offline and online. These three propositions become the basis for following up on further 
research. To create a hypothesis and prove empirically, we recommend using metide mix-methods for future research.

\section{Reference}

Amilia, W., Fatimatuzzahro, N., \& Choiron, M. (2018). Pendekatan Design Thinking Concept Pada Usaha Pengolahan Jahe Siap Minum Di Komunitas Wirausaha Desa Bangsalsari. In Prosiding seminar nasional APTA (pp. 435-439). repository.unej.ac.id.

Andriani, M., Samadhi, T. M. A. A., Siswanto, J., \& Suryadi, K. (2018). Aligning business process maturity level with SMEs growth in Indonesian fashion industry. International Journal of Organizational Analysis. https://doi.org/10.1108/IJOA-08-2017-1215

Ardyan, E., \& Sugiyarti, G. (2018). The influence of e-CRM capability and co-information sharing activity on product competitiveness and marketing performance of small and medium-sized enterprises. International Journal of Electronic Customer Relationship Management, 11(2). https://doi.org/10.1504/IJECRM.2018.090208

Astuti, P. P. D., Setyowati, Y., \& Utama, A. A. G. S. (2018). How to survive in the modern era: Integrated local entrepreneurs, the traditional market and the modern store. In A. B. N. \& R. H. Badri Munir Sukoco, Rahmat Heru Setianto \& Nidya Ayu Arina, Ade Gafar Abdullah (Ed.), Increasing Management Relevance and Competitiveness: Proceedings of the 2nd Global Conference on Business, Management and Entrepreneurship (GCBME 2017 Universitas Airlangga, Surabaya, Indonesia) (Eds, pp. 29-33). Taylor \& Francis Group.

Cahaya, V. T., Nugroho, R., \& P, D. S. P. (2016). Pengembangan Fasilitas Kawasan Wisata Green Canyon Dengan Penekanan Arsitektur Berkelanjutan Di Kecamatan Cijulang Kabupaten Pangandaran Jawa Barat. Arsitektura, 14(2). Retrieved from https://jurnal.uns.ac.id/Arsitektura/article/view/9072

Chan, A. (2018). Marketing Strategy of a Creative Industry Company in Bandung City. Review of Integrative Business and Economics Research, 7(2), 232-240. Retrieved from http://buscompress.com/journal-home.html

Dakhoir, A. (2018). Eksistensi Usaha Kecil Menengah dan Pasar Tradisional dalam Kebijakan Pengembangan Pasar Modern. Jurnal Studi Agama Dan Masyarakat, 14(1), 31-41. https://doi.org/10.23971/jsam.v14i1

Dhewanto, W., Lantu, D. C., Herliana, S., \& Azzahra, S. (2018). The entrance mode for small and medium enterprises in the Indonesian fashion industry to international market. International Journal of Business Innovation and Research, 16(3), 267-284. https://doi.org/10.1504/IJBIR.2018.092619

Fauzia, M. (2018, July). BI Sebut UMKM Kreatif di Indonesia Bisa Kalahkan Alibaba. Retrieved from https://ekonomi.kompas.com/read/2018/07/17/200800826/bi-sebutumkm-kreatif-di-indonesia-bisa-kalahkan-alibaba

Habyba, A. N., Djatna, T., \& Anggraeni, E. (2018). A System Analysis and Design for SMEs Product Presentation on E-commerce Website based on Kansei Engineering (Case Study : SMEs Products of Ponorogo Regency). In K. S. Lokman A., Yamanaka T., Lévy P., Chen K. (Ed.), Proceedings of the 7th International Conference on Kansei Engineering and Emotion Research 2018. KEER 2018. Advances in Intelligent Systems and Computing, vol 739 (pp. 20-29). Springer, Singapore.

Ika, A. (2018). Kontribusi Pasar Digital Terhadap PDB Diprediksi 10 Persen Tahun Ini. Kompas.com. Retrieved from 
https://ekonomi.kompas.com/read/2018/02/15/070000326/kontribusi-pasar-digitalterhadap-pdb-diprediksi-10-persen-tahun-ini

Irjayanti, M., \& Azis, A. M. (2012). Barrier Factors and Potential Solutions for Indonesian SMEs. Procedia Economics and Finance, 4(ISCMED), 3-12.

https://doi.org/10.1016/S2212-5671(12)00315-2

Jaswadi, Iqbal, M., \& Sumiadji. (2015). SME Governance in Indonesia - A Survey and Insight from Private Companies. Procedia Economics and Finance, 31, 387-398. https://doi.org/10.1016/S2212-5671(15)01214-9

Konsep Minapolitan. (2009). Retrieved from https://defishery.wordpress.com/2009/11/08/ikhtiologi/

Kumar, V., \& Pradhan, P. (2018). Trust Management Issues in Social-Media Marketing. In Social Media Marketing: Breakthroughs in Research and Practice (pp. 714-732). IGI Global. https://doi.org/10.4018/978-1-5225-5637-4.ch036

Kupita, W., \& Bintoro, R. W. (2012). Implementasi Kebijakan Zonasi Pasar Tradisional dan Pasar Modern (Studi di Kabupaten Purbalingga). Jurnal Dinamika Hukum, 12(1), 4560. Retrieved from http://www.dinamikahukum.fh.unsoed.ac.id/index.php/JDH/article/view/201/149

Kurniawan, D. (2018). Komunikasi Model Laswell Dan Stimulus-Organism- Response Dalam Mewujudkan Pembelajaran Menyenangkan. Jurnal Komunikasi Pendidikan, 2(1), 60-68. Retrieved from http://journal.univetbantara.ac.id/index.php/komdik/article/viewFile/65/60

Lefcoe, G. (2005). The Regulation of Superstores: The Legality of Zoning Ordinances Emerging from the Skirmishes between Wal-Mart and the United Food and Commercial Workers Union. https://doi.org/10.2139/ssrn.712801

Lisnawati, L., Wibowo, L. A., \& Andi, P. (2018). Empirical study of perceived quality information and perceived information security impact on online purchasing in Indonesia. In A. B. N. \& R. H. Badri Munir Sukoco, Rahmat Heru Setianto \& Nidya Ayu Arina, Ade Gafar Abdullah (Ed.), Increasing Management Relevance and Competitiveness: Proceedings of the 2nd Global Conference on Business, Management and Entrepreneurship (GC-BME 2017 Universitas Airlangga, Surabaya, Indonesia) (Eds, pp. 231-235). Taylor \& Francis Group.

Mercer, D. (2016). 7 Free Beginner Guides for Small Business Entrepreneurs. Sme Pals. Retrieved from https://smepals.com/startup/7-free-beginner-guides-small-businessentrepreneurs

Mizanti, I. R., Simatupang, T. M., \& Larso, D. (2018). Evaluation of emerging entrepreneurship policy. International Journal Economy Policy in Emerging Economies, 11(1/2). https://doi.org/10.1504/IJEPEE.2018.091034

Momongan, S. S. (2018). Beralih ke Online, UKM Bisa Lepas dari Cekikan Tengkulak. Retrieved from https://kumparan.com/@kumparanbisnis/beralih-ke-online-ukm-bisalepas-dari-cekikan-tengkulak-1533804230612386140

Muda, I., Maulana, W., Siregar, H. S., \& Indra, N. (2018). The Analysis of Effects of Good Corporate Governance on Earnings Management in Indonesia with Panel Data Approach. Iranian Economic Review, 22(2), 599-625. https://doi.org/10.22059/IER.2018.66169

Nurmayanti. (2018). Pemerintah Diminta Pacu UMKM Manfaatkan Era Digitalisasi. Retrieved from https://www.liputan6.com/bisnis/read/3494623/pemerintah-dimintapacu-umkm-manfaatkan-era-digitalisasi

Nurrohmah, A., \& Alfanur, F. (2016). Adopsi E-commerce Pada Usaha Mikro Dan Kecil Di Bandung (studi Kasus Subsektor Fesyen). In e-Proceeding of Management (Vol. 3, pp. 
1120-1127). Retrieved from

http://libraryeproceeding.telkomuniversity.ac.id/index.php/management/article/view/16 45

Pamungkas, B., Rohajawati, S., Fitrianah, D., \& Nurhaida, I. (2018). Proposing a Key Model e-Commerce Towards Digital Economy for Coastal Areas in Indonesia. In N. Kim,

Kuinam J.; Kim, Hyuncheol; Baek (Ed.), IT Convergence and Security 2017 (Vol. 450, pp. 98-105). Springer, Singapore. https://doi.org/10.1007/978-981-10-6454-8

Pemintakatan. (2018). In Bebas. Retrieved from https://id.wikipedia.org/wiki/Pemintakatan

Primus, J. (Ed.). (2018). Makin Besar, Peran UKM di Kawasan Asia Pasi k.

Rahman, F., \& Mawardi, M. K. (2017). Strategi Umkm Dalam Membangun Brand Toko Online Di Marketplace (Studi pada komunitas Tokopedia di Kota Bekasi. Jurnal Administrasi Bisnis (JAB), 53(1), 39-48. Retrieved from http://administrasibisnis.studentjournal.ub.ac.id/index.php/jab

Rapini, T., Farida, U., \& Santoso, A. (2018). Sari Cincau Ngrayun Equals with Modern Ready-to-Drink Beverage. In Proceedings of MICoMS 2017 (pp. 443-449). https://doi.org/10.1108/978-1-78756-793-1-00083

Rauf, A. (2016). Status Keberlanjutan Usaha Garam Rakyat Di Kecamatan Labakkang Kabupaten Pangkep. In Seminar Nasional Kelautan XI ” Penguatan Riset dan Teknologi dalam Rangka Meningkatkan Pengelolaan Sumberdaya Laut dan Pesisir" (pp. 11-23). Surabaya: Fakultas Teknik dan Ilmu Kelautan Universitas Hang Tuah.

Rosmery. (2018). Indonesia dalam Kubangan Neoliberalisme. In Prosiding Seminar Nasional Pakar (pp. 223-228). Retrieved from http://www.trijurnal.lemlit.trisakti.ac.id/index.php/pakar/article/view/2723/2351

Sarkum, S., Pramuka, B. A., \& Suroso, A. (2017a). Dynamic Marketing through Engagement: Answering the Role of Marketing Functions. International of Marketing, Communication and New Media, 5(9), 5-23.

Sarkum, S., Pramuka, B. A., \& Suroso, A. (2017b). Market Knowledge Of SMEs in Business Online: The Relationship with Engagement. In The 4th Sebelas Maret International Conference on Business, Economics, and Social Sciences (Vol. 4, pp. 239-241).

Sormin, R. B. D., Risambessy, A., \& Ferdinandus, S. J. (2016). Analisis Usaha Dan Kemitraan Pembudidaya Rumput Laut Eucheuma Cottonii Di Kota Ambon. In Seminar Nasional Kelautan XI " Penguatan Riset dan Teknologi dalam Rangka Meningkatkan Pengelolaan Sumberdaya Laut dan Pesisir" (pp. 1-54). Surabaya: Fakultas Teknik dan Ilmu Kelautan Universitas Hang Tuah.

Sulistyowati, L., Pardian, P., Syamsyiah, N., \& Deliana, Y. (2018). Development of small and medium business (SMES) of mango dodol processing to increase the added value (a case study in Ujungjaya Village, Indramayu District, West Java). In IOP Conf. Series: Earth and Environmental Science (pp. 1-8). https://doi.org/10.1088/1755$1315 / 142 / 1 / 012042$

Undang-Undang Republik Indonesia Nomor 7 Tahun 2014 Tentang Perdagangan, Pub. L. No. 5512 (2014). Indonesia. Retrieved from pih.kemlu.go.id/files/UU_Nomor_7_Tahun_2014.pdf

Widyastuti, N. W. (2018). Embedded social media and its implications for the readiness of sme's in asean economic community free trade. In The 1st International Conference on Social Sciences (pp. 443-453). Retrieved from https://jurnal.umj.ac.id/index.php/icss/article/view/2352/1962

$\mathrm{Wu}, \mathrm{M} .$, \& Lu, J. (2012). Theoretical research on professional management, trust mechanism and firm growth of chinese private high-tech SMEs. Asian Social Science, 8(15), 165170. https://doi.org/10.5539/ass.v8n15p165 
Yasmin, P. A. (2018, July). Jadi Penggerak Ekonomi, Begini Kondisi UMKM RI. Retrieved from https://finance.detik.com/berita-ekonomi-bisnis/d-4119386/jadi-penggerakekonomi-begini-kondisi-umkm-ri 


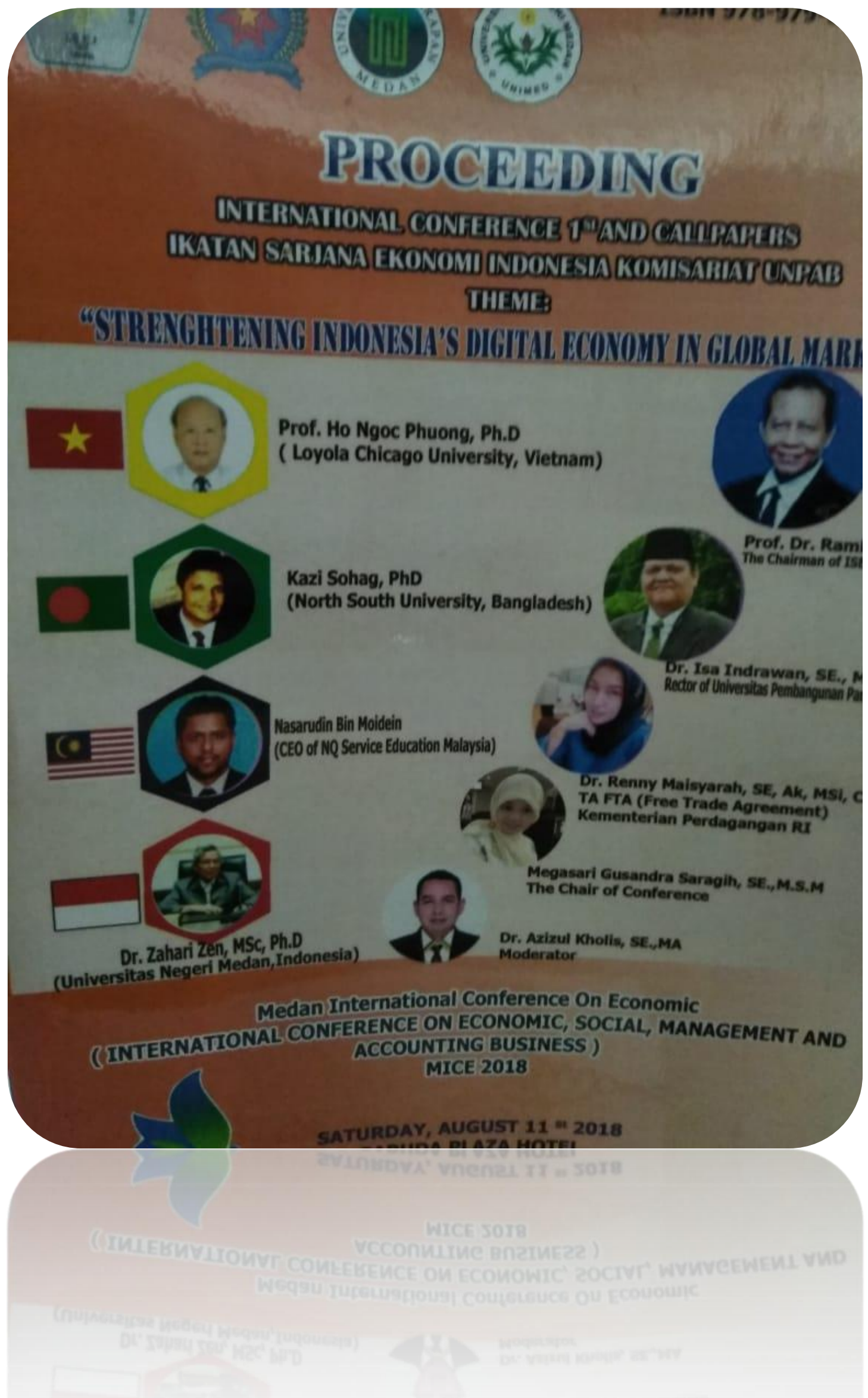




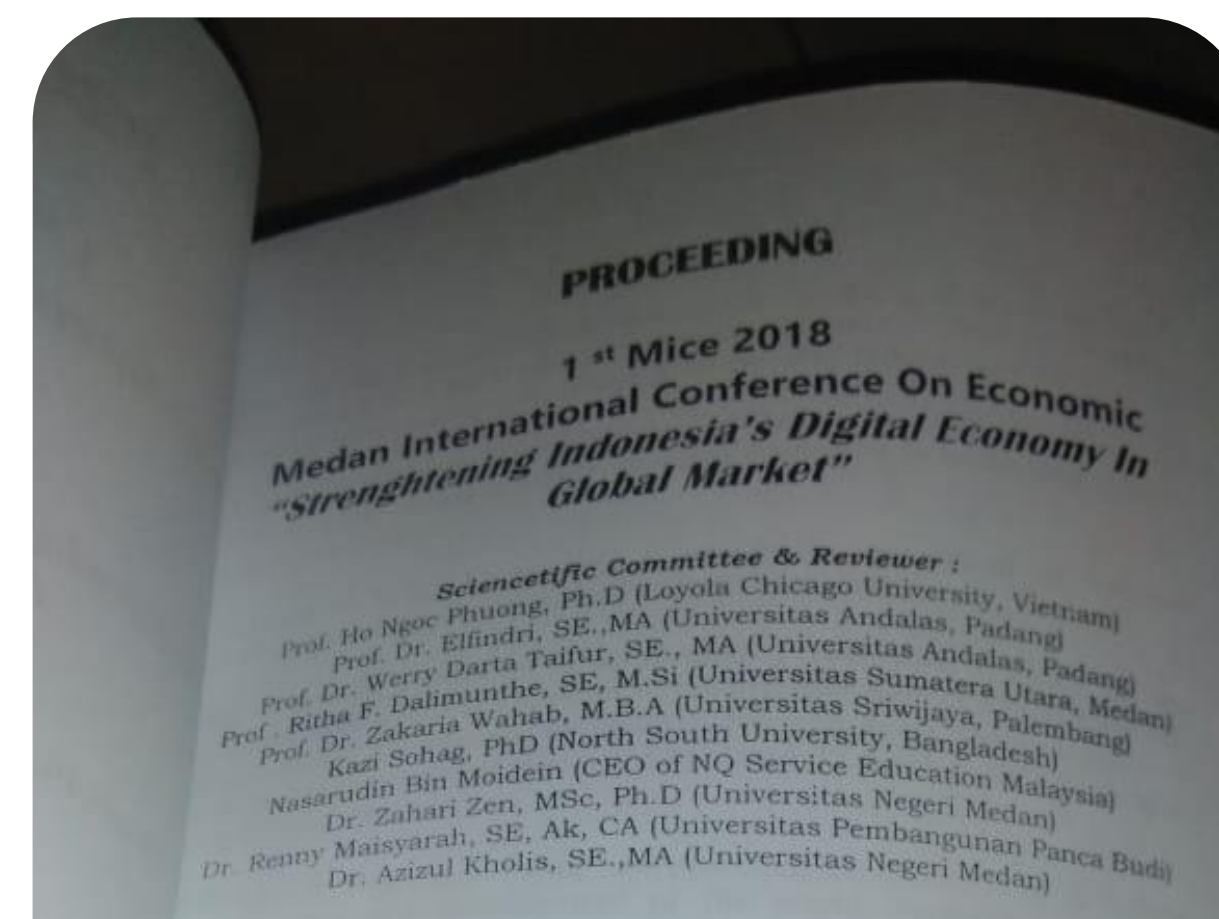

\section{Editor:}

Prof. Ho Ngoc Phuong, Ph.D

Prof. Dr. Ramli, MS

Kazi Sohag, PhD

Nasarudin Bin Moidein

Dr. Isa Indrawan, SE., MM

Dr. Renny Maisyarah, SE, Ak, CA

Megasari Gusandra, SE,,M.S.M

Dr. Azizul Kholis, SE.,MA

Dr. Zahari Zen, M.Sc

Cetakan Pertama, 2018

Medan, September 2018

ISBN : 978-979-3902-39-5

Katalog Dalam Terbitan Perpustakaan Nasional RI

\section{Penerbit :}

Badan Penelitian dan Pengembangan Provinsi Sumatera Utara

\section{Sekretariat dan Informasi :}

Jalan Gatot Subroto Km, 4,5 Medan. Sumatera Utara 20122

Website : www.isei-unpab.com

Email : isei.unpab@gmail.com 


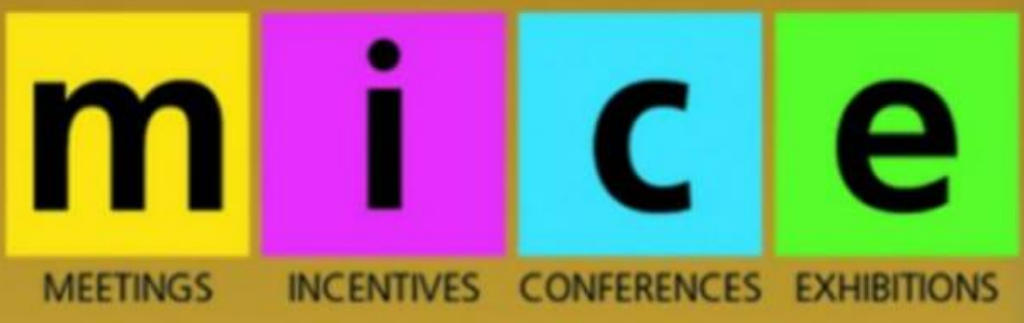

Badan Penelititan dan Pengembangan

Provinsi Sumafera UTara 2018

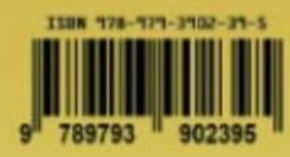

